\title{
Synthesis and Evaluation of Curcumin-Related Compounds Containing Inden-2-one for Their Effects on Human Cancer Cells
}

\author{
Daiying Zhou, ${ }^{a}$ Ning Ding, ${ }^{c}$ Suqing Zhao, ${ }^{e}$ Dongli Li, ${ }^{e}$ Jeremiah Van Doren,${ }^{c}$ Yu Qian, ${ }^{d}$ \\ Xingchuan Wei, ${ }^{*, b}$ and Xi Zheng ${ }^{*, c}$ \\ ${ }^{a}$ Guangdong Food and Drug Vocational College; Guangzhou 510520, China: ${ }^{b}$ Department of Chemistry and \\ Chemical Engineering, Guangzhou University; ${ }^{e}$ Allan H Conney Laboratory for Research, Institute of Natural \\ Medicinal Chemistry \& Green Chemistry, Guangdong University of Technology; Guangzhou 510006, China: ${ }^{c}$ Ernest \\ Mario School of Pharmacy, Rutgers, the State University of New Jersey; Piscataway, NJ 08854, U.S.A.: and ${ }^{d}$ School \\ of Chemistry and Chemical Engineering, South China University of Technology; Guangzhou 510640, China. \\ Received June 26, 2014; accepted September 9, 2014
}

\begin{abstract}
Indanones are very useful molecules as starting building blocks for the synthesis of biologically active compounds. A series of novel curcumin-related compounds containing indan-2-one were synthesized and screened for anticancer activities. The structures were confirmed by spectral data (IR, NMR, and Mass). Inhibitory effects of these compounds on the growth of prostate cancer PC-3 cells, pancreatic cancer BxPC-3 cells, colon cancer HT-29 cells, lung cancer H1299 cells and non-tumorigenic human prostate epithelial RWPE-1 cells were determined by the 3-(4,5-dimethylthiazol-2-yl)-2,5-diphenyltetrazolium bromide (MTT) assay. The $\mathrm{IC}_{50}$ for compound IND-4 was lower than $1 \mu \mathrm{M}$ in the four cancer cell lines. The present study indicates that IND-4 may have useful effects on human cancer cells.
\end{abstract}

Key words curcumin-related compound; cancer cell; inden-2-one

Curcumin isolated form turmeric: the "Golden spice," possesses many biological properties. Numerous studies have shown that curcumin possesses multifunctional pharmacological properties including anti-oxidant activity, ${ }^{1-3)}$ antiinflammatory activity ${ }^{4-6)}$ and anticancer activity. ${ }^{7-11}$ Curcumin has been evaluated in clinical trials for the treatment of liver disease, rheumatoid arthritis, infectious diseases and cancer. Despite its safety, the clinical usefulness of curcumin is diminished by extensive first-pass metabolism, resulting in low oral bioavailability. ${ }^{12-14)}$ In the last decade curcumin has been greatly explored. Various synthetic analogues have been prepared and evaluated for various pharmacological activities. ${ }^{15-22)}$ Introduction of methoxy group on the aromatic rings of curcumin has been found to enhance its antitutor activity. ${ }^{23)}$ Indan ring frameworks are ubiquitous in a large number of natural products, bioactive and pharmaceutically interesting molecules. Indanones therefore are very useful molecules as starting building blocks for the synthesis of biologically active compounds. ${ }^{24)}$ A recent study demonstrated that curcuminrelated compounds with an inden-2-one had enhanced activity and lower cytoxicity. ${ }^{25,26)}$

In the present study, seven curcumin-related compounds using inden-2-one as a linker and various substituents on the aryl rings (Chart 1) were synthesized and evaluated for their effects against four human cancer cell lines. These compounds were previously not reported except for IND-1. Results of the present study showed that some of the compounds had potent effects for inhibiting the growth of PC-3, BxPC-3, HT-29, H1299 and RWPE-1 cells.

\section{RESULTS AND DISCUSSION}

Chemistry A series of curcumin-related compounds containing inden-2-one were synthesized by coupling the appropriate substituted benzaldehyde with inden-2-one (Chart 1).

The authors declare no conflict of interest.
The synthesis and characterization of these compounds were not previously reported. Structures of curcumin and curcumin-related compounds containing an inden-2-one moiety are shown in Fig. 1.

Inhibitory Effects of Curcumin-Related Compounds Containing Inden-2-one toward Cultured Human Prostate, Pancreatic, Colon, Lung Cancer Cells and Non-tumorigenic Human Prostate Epithelial Cells The inhibitory effects of seven curcumin-related compounds containing inden-2-one on the growth of cultured prostate cancer PC-3 cells, pancreatic cancer BxPC-3 cells, colon cancer HT-29 cells, lung cancer cells H1299 and non-tumorigenic human prostate epithelial RWPE-1 cells were determined by using the 3-(4,5-dimethylthiazol-2-yl)-2,5-diphenyltetrazolium bromide (MTT) assay. For this experiment, curcumin was evaluated as a positive control in each incubation. The inhibitory effect of curcumin toward same cell lines did not vary significantly between the different incubations. Data from all curcumin treatment in each cell line were averaged and presented in Table 1.

All compounds had stronger inhibitory effects than curcumin as determined by the MTT assay except IND-3 in lung cancer H1299 cells. Among the seven curcumin-related compounds tested, IND-4 exhibited exceptionally potent inhibitory effects on the growth of cultured PC-3, BxPC-3, HT-29 and $\mathrm{H} 1299$ cells. $\mathrm{The} \mathrm{IC}_{50}$ for this compound was $\leq 1 \mu \mathrm{M}$ in all four cell lines, indicating that IND-4 was approximately 20fold more active than curcumin. As shown in Table 1 , the $\mathrm{IC}_{50}$ values of all seven curcumin-related compounds ranged from 0.64 to $18.94 \mu \mathrm{M}$ in the four cancer cell lines studied.

When comparing the results of MTT assay in prostate cancer PC-3 and non-tumorigenic prostate epithelial RWPE-1 cells, all compounds except curcumin had lower cytoxicity (higher $\mathrm{IC}_{50}$ ) in RWPE-1 cells than in PC-3 cells. As shown in Table 1, the $\mathrm{IC}_{50}$ values of IND-4 in RWPE-1 cells was approximately 14 -fold higher than that in PC-3 cells indicating this compound is more toxic to cancer cells than to noncancer cells. 


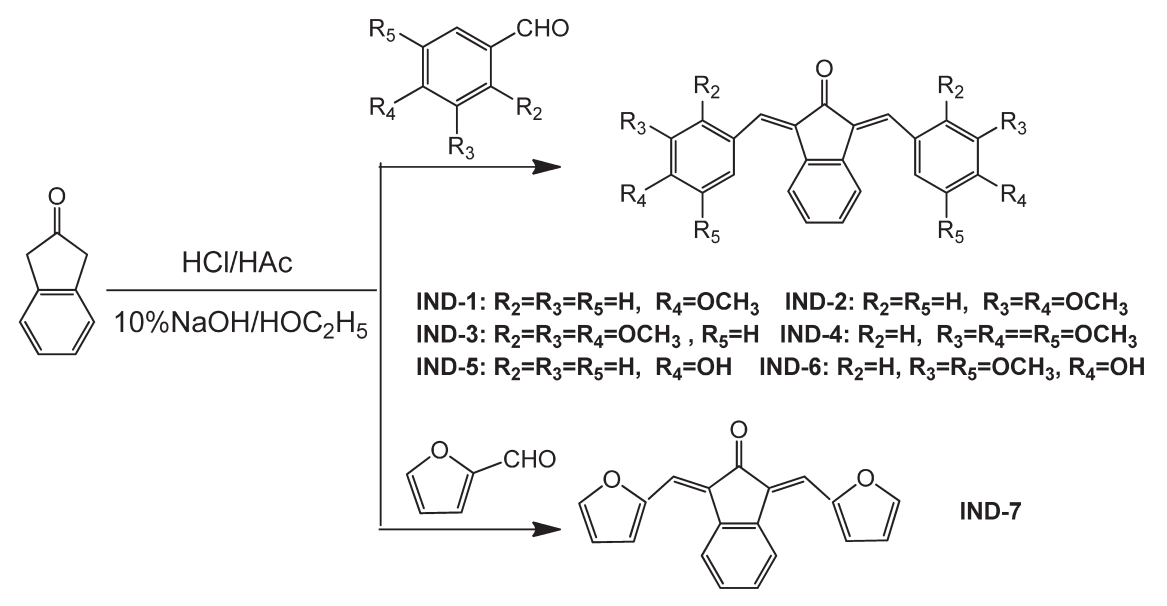

Chart 1. Synthesis of Curcumin-Related Compounds<smiles>COc1cc(/C=C/C(=O)CC(=O)/C=C/c2ccc(O)c(OC)c2)ccc1O</smiles>

(1E,6E)-1,7-Bis(4-hydroxy-3-methoxyphenyl)- 1,6heptadiene-3,5-dione (Curcumin)<smiles>COc1ccc(/C=C2\C(=O)/C(=C\c3ccc(OC)c(OC)c3)c3ccccc32)cc1OC</smiles>

(1E,3E)-1,3-bis(3,4-dimethoxybenzylidene)-1,3dihydroinden-2-one (IND-2)<smiles>COc1cc(C=C2C(=O)C(=Cc3cc(OC)c(OC)c(OC)c3)c3ccccc32)cc(OC)c1OC</smiles>

(1E,3E)-1,3-bis(3,4,5-trimethoxybenzylidene)-1,3dihydroinden-2-one (IND-4)<smiles>COc1cc(C=C2C(=O)c3ccccc3C2=Cc2cc(OC)c(O)c(OC)c2)cc(OC)c1O</smiles>

dimethoxybenzylidene)-1,3-dihydroinden-2-one (IND-6)<smiles>COc1ccc(/C=C2\C(=O)/C(=C\c3ccc(OC)cc3)c3ccccc32)cc1</smiles>

(1E,3E)-1,3-bis(4-methoxybenzylidene)-1,3dihydroinden-2-one (IND-1)<smiles>COc1ccc(C=C2C(=O)C(=Cc3ccc(OC)c(OC)c3OC)c3ccccc32)c(OC)c1OC</smiles>

(1E,3E)-1,3-bis(2,3,4-trimethoxybenzylidene)1,3-dihydroinden-2-one (IND-3)<smiles>O=C1C2=CCCC=C2C(=C\c2ccc(O)cc2)/C1=C\c1ccc(O)cc1</smiles>

(1E,3E)-1,3-bis(4-hydroxybenzylidene)-1,3dihydroinden-2-one (IND-5)

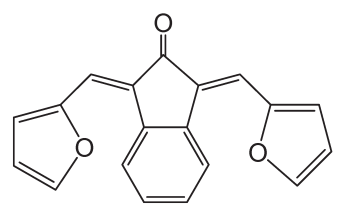

(1E,3E)-1,3-bis(furan-2-ylmethylene)-1,3dihydroinden-2-one (IND-7)

Fig. 1. Structures of Curcumin and Curcumin-Related Compounds

Earlier studies on the analysis of the relationship between the structures of curcumin-related compounds and their ability to inhibit the growth of cultured cancer cells showed that the linker, the aromatic rings and steric hinderance are all very important for activity. ${ }^{27)}$ Comparing different substituted groups on curcumin-related compounds with the same linker, we found that introduction of methoxy groups on the aromatic rings enhanced anticancer activity. ${ }^{22)}$ IND-4 showed some increases in activities over the corresponding IND-1 and IND-2. For the same linker and same aromatic rings, such as IND-3 and IND-4, steric hinderance is very important for activity, IND-4 had increased activity as compared to IND-3. As shown in Table 1 , the $\mathrm{IC}_{50}$ values of IND-4 was approximately 12- to 19-fold more active than IND-3 in the four cancer cells, which suggests that less steric hinderance compounds may enhance their antitumor activities by having interactions with the DNA of cancer cells.

\section{CONCLUSION}

In conclusions, we found that curcumin-related compounds with an indan-2-one as the core structure had a more potent inhibitory effect on cancer cells than curcumin. Compounds IND-4 exhibited particularly potent inhibitory effects on the 
Table 1. Inhibitory Effects of Curcumin and Curcumin-Related Compounds on the Growth of PC-3, Panc-1, HT-29 and H1299 Cells

\begin{tabular}{|c|c|c|c|c|c|}
\hline \multirow{2}{*}{ Compound } & \multicolumn{5}{|c|}{$\mathrm{IC}_{50}(\mu \mathrm{M})$} \\
\hline & PC-3 & BxPC-3 & HT-29 & H1299 & RWPE-1 \\
\hline Curcumin & $19.98 \pm 2.4$ & $18.25 \pm 2.2$ & $18.74 \pm 2.2$ & $18.93 \pm 2.1$ & $15.62 \pm 1.5$ \\
\hline IND-1 & $8.30 \pm 0.9$ & $3.12 \pm 0.4$ & $4.17 \pm 0.5$ & $3.39 \pm 0.4$ & $39.26 \pm 5.1$ \\
\hline IND-2 & $3.05 \pm 0.4$ & $5.27 \pm 0.6$ & $6.98 \pm 0.8$ & $5.18 \pm 0.6$ & $18.13 \pm 5.4$ \\
\hline IND-3 & $10.06 \pm 1.3$ & $14.30 \pm 1.6$ & $12.31 \pm 1.4$ & $18.94 \pm 2.5$ & $18.44 \pm 1.1$ \\
\hline IND-4 & $0.64 \pm 0.1$ & $0.99 \pm 0.1$ & $0.98 \pm 0.1$ & $0.95 \pm 0.1$ & $9.12 \pm 0.4$ \\
\hline IND-5 & $9.6 \pm 1.1$ & $4.62 \pm 0.5$ & $14.47 \pm 1.4$ & $8.83 \pm 0.9$ & $29.23 \pm 3.9$ \\
\hline IND-6 & $2.46 \pm 0.3$ & $1.72 \pm 0.2$ & $3.65 \pm 0.4$ & $2.95 \pm 0.3$ & $4.2 \pm 0.5$ \\
\hline IND-7 & $8.12 \pm 0.9$ & $7.18 \pm 0.8$ & $7.96 \pm 0.7$ & $6.00 \pm 0.7$ & $27.66 \pm 2.3$ \\
\hline
\end{tabular}

Human prostate cancer PC-3, pancreas cancer BxPC-3, colon cancer HT-29, Lung cancer cells H1299 and non-tumorigenic human prostate epithelial RWPE-1 cells were seeded at a density of $2 \times 10^{4}$ cells $/ \mathrm{mL}$ of medium in 96 -well plates $(0.2 \mathrm{~mL} /$ well $)$ and incubated for $24 \mathrm{~h}$. The cells were then treated with various concentrations $(0.2-50 \mu \mathrm{M})$ of the different compounds for $72 \mathrm{~h}$. Effects of the different compounds on the growth of PC-3, BxPC-3, HT-29, H1299 and RWPE-1 cells were determined by the MTT assay.

growth of cultured prostate cancer PC-3 cells, pancreatic cancer BxPC-3 cells, lung cancer H1299 and colon cancer HT-29 cells. The $\mathrm{IC}_{50}$ for IND-4 in all four cell lines was less than $1 \mu \mathrm{M}$. From preliminary studies of structure-activity relationships, it was found that indane as a core structure and methoxy groups in the aromatic rings may be promising lead structures for new agents with potent anticancer activity.

\section{MATERIALS AND METHODS}

General Procedures Melting points were determined on a Yanagimoto micro melting apparatus and were uncorrected. The ${ }^{1} \mathrm{H}-\mathrm{NMR}$ spectra were measured on a Varian Gemini-2000 spectrometer using dimethyl sulfoxide (DMSO) as solvent unless otherwise specified. Chemical shifts for ${ }^{1} \mathrm{H}-\mathrm{NMR}(400 \mathrm{MHz})$ and ${ }^{13} \mathrm{C}-\mathrm{NMR}(101 \mathrm{MHz})$ were expressed in ppm units with tetramethylsilane (TMS) as an internal standard. Multiplicities were recorded as s (singlet), brs (broad singlet), d (doublet), t (triplet), q (quartet), and m (multiplet). Mass spectra were obtained on an LC-MS-2010 A spectrometer with electrospray ionization (ESI). Elemental analyses were performed on an elemental analyser (Vario El). Thin-layer chromatography (TLC) was performed on Merck silica gel plates (DC-60 F254). Curcumin was isolated from the extract of Curcuma longa LinN according to a previous report. ${ }^{26)}$ All reagents (highest grade) were used as received unless otherwise stated.

Synthesis of Curcumin-Related Compounds A total of 7 curcumin-related compounds containing inden-2-one were synthesized as previously described with modification. ${ }^{27,28)}$ A mixture of the appropriate aldehyde $(0.012 \mathrm{~mol})$ and the inden-2-one $(0.004 \mathrm{~mol})$ was dissolved in glacial acetic acid saturated with anhydrous hydrogen chloride and heated in a water bath at $40^{\circ} \mathrm{C}$ for $3 \mathrm{~h}$, the mixture was treated with cold water and filtered. The solid obtained was then washed and dried. The crude product was recrystallized from appropriate solvents (methanol or ethanol). Curcumin was isolated from the extract of Curcuma longa LiNN according to a previous report. $^{28)}$

(1E,3E)-1,3-Bis(4-methoxybenzylidene)-1,3-dihydroinden2-one (IND-1) This compound was characterized earlier as PMIND in ref. 25.

(1E,3E)-1,3-Bis(3,4-dimethoxybenzylidene)-1,3-dihydroinden-2-one (IND-2) Yellow powder. Yield 85\%. mp 252.6-254.1 ${ }^{\circ} \mathrm{C}$. IR (KBr): 3021, 2839, 1706, 1560, 1507, 1420,
$1308 \mathrm{~cm}^{-1} .{ }^{1} \mathrm{H}-\mathrm{NMR}\left(400 \mathrm{MHz}, \mathrm{CDCl}_{3}\right) \delta(\mathrm{ppm}): 7.58(\mathrm{~s}, 2 \mathrm{H}$, $-\mathrm{CH}=$ ), 7.50 (s, 2H, ArH), 7.53-7.18 (m, 4H, ArH), 6.90-6.73 $(\mathrm{m}, 4 \mathrm{H}, \mathrm{ArH}), 3.98\left(\mathrm{~s}, 12 \mathrm{H},-\mathrm{OCH}_{3}\right) .{ }^{13} \mathrm{C}-\mathrm{NMR}(101 \mathrm{MHz}$, $\left.\mathrm{CDCl}_{3}\right) \delta: 193.28,152.34,149.62,140.06,135.02,132.93$, 130.42, 129.46, 128.41, 120.51, 115.66, 111.77, 57.33, 57.14. Electron ionization (EI)-MS $(\mathrm{m} / \mathrm{z})$ : $428\left(\mathrm{M}^{+}\right)$.

(1E,3E)-1,3-Bis(2,3,4-trimethoxybenzylidene)-1,3-dihydroinden-2-one (IND-3) Yellow powder. Yield 72\%. mp $166.0-167.5^{\circ} \mathrm{C}$. IR (KBr): 3100, 2940, 1706, 1594, 1496, 1409 , 1302, 1173, 1033, $826 \mathrm{~cm}^{-1}$. ${ }^{1} \mathrm{H}-\mathrm{NMR}\left(400 \mathrm{MHz}, \mathrm{CDCl}_{3}\right) \delta$ (ppm): 7.75 (s, 2H, $-\mathrm{CH}=), 7.60-7.35$ (m, 4H, ArH), 6.91-6.75 $(\mathrm{m}, 4 \mathrm{H}, \mathrm{ArH}), 3.96\left(\mathrm{~s}, 18 \mathrm{H},-\mathrm{OCH}_{3}\right) .{ }^{13} \mathrm{C}-\mathrm{NMR}(101 \mathrm{MHz}$, $\left.\mathrm{CDCl}_{3}\right) \quad \delta: 195.45,156.45,154.57,143.78,138.63,133.78$, $130.54,129.76,125.50,124.60,123.51,108.31,62.96,62.39$, 57.47. EI-MS $(\mathrm{m} / \mathrm{z}): 488\left(\mathrm{M}^{+}\right)$.

(1E,3E)-1,3-Bis(3,4,5-trimethoxybenzylidene)-1,3-dihydroinden-2-one (IND-4) Orange crystal. Yield 78\%. mp 177.9-180. $6^{\circ} \mathrm{C}$. IR (KBr): 3066, 2839, 1706, 1577, 1501, 1457, 1420, 1280, 1241, 1168, $831 \mathrm{~cm}^{-1}$. ${ }^{1} \mathrm{H}-\mathrm{NMR}(400 \mathrm{MHz}$, $\left.\mathrm{CDCl}_{3}\right) \delta(\mathrm{ppm}): 7.91(\mathrm{~s}, 2 \mathrm{H},-\mathrm{CH}=), 7.63-7.38(\mathrm{~m}, 4 \mathrm{H}, \mathrm{ArH})$, 6.93-6.78 (m, 4H, ArH), $3.90\left(\mathrm{~s}, 18 \mathrm{H},-\mathrm{OCH}_{3}\right) .{ }^{13} \mathrm{C}-\mathrm{NMR}$ $\left(101 \mathrm{MHz}, \mathrm{CDCl}_{3}\right) \delta: 195.65,154.69,140.53,138.60,134.62$, $133.73,131.84,130.09,125.11,107.70,62.39$, 57.60. EI-MS $(\mathrm{m} / \mathrm{z}): 488\left(\mathrm{M}^{+}\right)$.

(1E,3E)-1,3-Bis(4-hydroxybenzylidene)-1,3-dihydroinden2-one (IND-5) Deep green powder. Yield 75\%. mp 272.4-273.1 ${ }^{\circ} \mathrm{C}$. IR (KBr): 3652, 3063, 1693, 1511, $841 \mathrm{~cm}^{-1}$. ${ }^{1} \mathrm{H}-\mathrm{NMR}$ (400 MHz, DMSO) $\delta$ (ppm): 9.49 (s, 2H, -OH), 7.86 $(\mathrm{s}, 2 \mathrm{H},-\mathrm{CH}=), 7.57-7.31(\mathrm{~m}, 4 \mathrm{H}, \mathrm{ArH}), 7.25-7.11(\mathrm{~m}, 4 \mathrm{H}$, ArH), 6.93-6.78 (m, 4H, ArH), ${ }^{13} \mathrm{C}-\mathrm{NMR}$ (101 MHz, DMSO) $\delta: 195.00,161.02,138.33,135.30,133.25,131.82,130.58$, 126.82, 124.32, 117.44. EI-MS (m/z): $340\left(\mathrm{M}^{+}\right)$.

(1E,3E)-1,3-Bis(4-hydroxy-3,5-dimethoxybenzylidene)-1,3dihydroinden-2-one (IND-6) Yellowish green powder. Yield 83\%. mp 220.1-221.7 ${ }^{\circ} \mathrm{C}$. IR (KBr): 3527, 3108, 2934, 1674, $1570,1461,1357,1271,1129,1109,1062,810 \mathrm{~cm}^{-1} .{ }^{1} \mathrm{H}-\mathrm{NMR}$ $\left(400 \mathrm{MHz}, \mathrm{CDCl}_{3}\right) \delta$ (ppm): $9.02(\mathrm{~s}, 2 \mathrm{H},-\mathrm{OH}), 7.82$ (s, 2H, $-\mathrm{CH}=)$, 7.62-7.35 (m, 4H, ArH), 6.93-6.78 (m, 4H, ArH), $3.96\left(\mathrm{~s}, 12 \mathrm{H},-\mathrm{OCH}_{3}\right) \cdot{ }^{13} \mathrm{C}-\mathrm{NMR}\left(101 \mathrm{MHz}, \mathrm{CDCl}_{3}\right) \delta: 194.06$, $148.44,147.93$, 135.13, 129.80, 127.59, 124.78, 120.79, 110.98, 107.72, 57.79. EI-MS $(\mathrm{m} / \mathrm{z}): 460\left(\mathrm{M}^{+}\right)$.

(1E,3E)-1,3-Bis(furan-2-ylmethylene)-1,3-dihydroinden2-one (IND-7) Tan powder. Yield 81\%. mp 173.5-174. $6^{\circ} \mathrm{C}$. IR (KBr): 3108, 1702, 1612, 1566, 1481, 1419, 1283, 1155, 1020, $927 \mathrm{~cm}^{-1} .{ }^{1} \mathrm{H}-\mathrm{NMR}$ (400 MHz, DMSO) $\delta(\mathrm{ppm}): 8.14(\mathrm{~s}$, 
$2 \mathrm{H},-\mathrm{CH}=)$, 7.98-7.54 (m, 4H, ArH), 6.80-6.51 (m, 6H, FuH).

${ }^{13} \mathrm{C}-\mathrm{NMR}$ (101 MHz, DMSO) $\delta: 193.34,148.97,148.36,143.48$, $140.93,136.03,129.51,126.51,112.30,112.08$. EI-MS $(\mathrm{m} / \mathrm{z}): 288$ $\left(\mathrm{M}^{+}\right)$.

Cell Culture and Reagents PC-3, BxPC-3, HT-29, H1299 and RWPE-1 cells were obtained from the American Type Culture Collection (ATCC, Rockville, MD, U.S.A.). RPMI-1640 tissue culture medium, penicillin-streptomycin, L-glutamine and fetal bovine serum (FBS) were from Gibco (Grand Island, NY, U.S.A.). The cells were maintained in RPMI-1640 culture medium, which were supplemented with $10 \%$ FBS, penicillin (100 units $/ \mathrm{mL})$-streptomycin $(100 \mu \mathrm{g} / \mathrm{mL})$ and L-glutamine $(300 \mu \mathrm{g} / \mathrm{mL})$. Cultured cells were grown at $37^{\circ} \mathrm{C}$ in a humidified atmosphere of $5 \% \mathrm{CO}_{2}$ and were passaged twice a week. Curcumin-related compounds were dissolved in DMSO and the final concentration of DMSO in all experiments was $0.1 \%$.

MTT PC-3, BxPC-3, HT-29, H1299 and RWPE-1 cells were seeded at a density of $2 \times 10^{4}$ cells $/ \mathrm{mL}$ of medium in 96 -well plate $(0.2 \mathrm{~mL} /$ well $)$ and incubated for $24 \mathrm{~h}$. The cells were then treated with various concentrations $(0.2-20 \mu \mathrm{M})$ of curcumin-related compounds containing inden-2-one for $72 \mathrm{~h}$. After treatment, MTT was added to each well of the plate and incubated for $1 \mathrm{~h}$. After careful removal of the medium, $0.1 \mathrm{~mL}$ DMSO was added to each well, and absorbance at $550 \mathrm{~nm}$ was recorded on a microplate reader.

Acknowledgments The present study was supported by China National Science Foundation Grants (81272452), and by Medical Scientific Research Foundation of Guangdong Province (B2014072), and by Guangdong Province Science and Technology Grants (2011B050400028) and by Guangzhou Science and Technology Grants (12C32011623).

\section{REFERENCES}

1) Du ZY, Jiang YF, Tang ZK, Mo RQ, Xue GH, Lu YJ, Zheng $X$, Dong $\mathrm{CH}$, Zhang $\mathrm{K}$. Antioxidation and tyrosinase inhibition of polyphenolic curcumin analogs. Biosci. Biotechnol. Biochem., 75, 2351-2358 (2011).

2) Masuda $T$, Maekawa $T$, Hidaka $K$, Bando $H$, Takeda $Y$, Yamaguchi $\mathrm{H}$. Chemical studies on antioxidant mechanism of curcumin: analysis of oxidative coupling products from curcumin and linoleate. $J$. Agric. Food Chem., 49, 2539-2547 (2001).

3) Menon VP, Sudheer AR. Antioxidant and anti-inflammatory properties of curcumin. Adv. Exp. Med. Biol., 595, 105-125 (2007).

4) Jayaprakasha GK, Rao Jaganmohan L, Sakariah KK. Antioxidant activities of curcumin, demethoxycurcumin and bisdemethoxycurcumin. Food Chem., 98, 720-724 (2006).

5) Chainani-Wu N. Safety and anti-inflammatory activity of curcumin: a component of tumeric (Curcuma longa). J. Altern. Complement. Med., 9, 161-168 (2003).

6) Jurenka JS. Anti-inflammatory properties of curcumin, a major constituent of Curcuma longa: a review of preclinical and clinical research. Altern. Med. Rev., 14, 141-153 (2009).

7) Kuttan R, Bhanumathy P, Nirmala K, George MC. Potential anticancer activity of turmeric (Curcuma longa). Cancer Lett., 29, 197-202 (1985)

8) Huang MT, Smart RC, Wong CQ, Conney AH. Inhibitory effect of curcumin, chlorogenic acid, caffeic acid, and ferulic acid on tumor promotion in mouse skin by 12- $O$-tetradecanoylphorbol-13-acetate. Cancer Res., 48, 5941-5946 (1988).

9) Huang MT, Wang ZY, Georgiadis CA, Laskin JD, Conney AH. In- hibitory effects of curcumin on tumor initiation by benzo[a]pyrene and 7,12-dimethylbenz[a]anthracene. Carcinogenesis, 13, 2183-2186 (1992).

10) Huang MT, Lou YR, Ma W, Newmark HL, Reuhl KR, Conney AH. Inhibitory effects of dietary curcumin on forestomach duodenal, and colon carcinogenesis in mice. Cancer Res., 54, 5841-5847 (1994).

11) Rao CV, Rivenson A, Simi B, Reddy B. Chemoprevention of colon carcinogenesis by dietary curcumin, a naturally occurring plant phenolic compound. Cancer Res., 55, 259-266 (1995).

12) Anand $P$, Sundaram $C$, Jhurani $S$, Kunnumakkara AB, Aggarwal BB. Curcumin and cancer: an 'old-age' disease with an 'age-old' solution. Cancer Lett., 267, 133-164 (2008).

13) Dhillon N, Aggarwal BB, Newman RA, Wolff RA, Kunnumakkara $\mathrm{AB}$, Abbruzzese JL, Ng CS, Badmaev V, Kurzrock R. Phase II trial of curcumin in patients with advanced pancreatic cancer. Clin. Cancer Res., 14, 4491-4499 (2008).

14) Cheng AL, Hsu CH, Lin JK, Hsu MM, Ho YF, Shen TS, Ko JY, Lin JT, Lin BR, Ming-Shiang W, Yu HS, Jee SH, Chen GS, Chen TM, Chen CA, Lai MK, Pu YS, Pan MH, Wang YJ, Tsai CC, Hsieh CY. Phase I clinical trial of curcumin, a chemopreventive agent, in patients with high-risk or pre-malignant lesions. Anticancer Res., 21 (4B), 2895-2900 (2001).

15) Adams BK, Ferstl EM, Davis MC, Herold M, Kurtkaya S, Camalier RF, Hollingshead MG, Kaur G, Sausville EA, Rickles FR, Snyder JP, Liotta DC, Shoji M. Synthesis and biological evaluation of novel curcumin analogs as anti-cancer and antiangiogenesis agents. Bioorg. Med. Chem., 12, 3871-3883 (2004).

16) Lee KH, Ab Aziz FH, Syahida A, Abas F, Shaari K, Israf DA, Lajis NH. Synthesis and biological evaluation of curcumin-like diarylpentanoid analogues for anti-inflammatory, antioxidant and antityrosinase activities. Eur. J. Med. Chem., 44, 3195-3200 (2009).

17) Zhao C, Yang J, Wang Y, Liang D, Yang X, Li X, Wu J, Wu X, Yang S, Li X, Liang G. Synthesis of mono-carbonyl analogues of curcumin and their effects on inhibition of cytokine release in LPS-stimulated RAW264.7 macrophages. Bioorg. Med. Chem., 18, 2388-2393 (2010).

18) Yadav B, Taurin S, Rosengren RJ, Schumacher M, Diederich M, Somers-Edgar TJ, Larsen L. Synthesis and cytotoxic potential of heterocyclic cyclohexanone analogues of curcumin. Bioorg. Med. Chem., 18, 6701-6707 (2010).

19) Sun A, Shoji M, Lu YJ, Liotta DC, Snyder JP. Synthesis of EF24tripeptide chloromethyl ketone: a novel curcumin-related anticancer drug delivery system. J. Med. Chem., 49, 3153-3158 (2006).

20) Somers-Edgar TJ, Taurin S, Larsen L, Chandramouli A, Nelson MA, Rosengren R. Mechanisms for the activity of heterocyclic cyclohexanone curcumin derivatives in estrogen receptor negative human breast cancer cell lines. Invest. New Drugs, 29, 87-97 (2011).

21) Zhou DY, Zhang K, Conney AH, Ding N, Cui XX, Wang H, Verano M, Zhao SQ, Fan YX, Zheng X, Du ZY. Synthesis and evaluation of curcumin-related compounds containing benzyl piperidone for their effects on human cancer cells. Chem. Pharm. Bull., 61, $1149-1155$ (2013).

22) Subramaniam D, May R, Sureban SM, Lee KB, George R, Kuppusamy P, Ramanujam RP, Hideg K, Dieckgraefe BK, Houchen $\mathrm{CW}$, Anant S. Diphenyl difluoriketone: a curcumin derivative with potent in vivo anticancer activity. Cancer Res., 68, 1962-1969 (2008).

23) Ohori H, Yamakoshi H, Tomizawa M, Shibuya M, Kakudo Y, Takahashi A, Takahashi S, Kato S, Suzuki T, Ishioka C, Iwabuchi Y, Shibata H. Mol. synthesis and biological analysis of new curcumin analogues bearing an enhanced potential for the medicinal treatment of cancer. Mol. Cancer Ther., 5, 2563-2571 (2006).

24) Senaiar RS, Teske JA, Young D, Deiters A. Synthesis of indanones via solid-supported $[2+2+2]$ cyclotrimerization. J. Org. Chem., 72 , 7801-7804 (2007). 
25) Karthikeyan NS, Sathiyanarayanan KI, Aravindan PG, Giridharan P. Synthesis, crystal structure, and anticancer properties of cyclic monocarbonyl analogs of curcumin. Med. Chem. Res., 20, 81-87 (2011).

26) Dimmock JR, Das U, Gul HI, Kawase M, Sakagami H, Baráth Z, Ocsovsky I, Molnár J. 3-Arylidene-1-(4-nitrophenylmethylene)-3,4dihydro-1H-naphthalen-2-ones and related compounds displaying selective toxicity and reversal of multidrug resistance in neoplastic cells. Bioorg. Med. Chem. Lett., 15, 1633-1636 (2005).

27) Wei X, Du ZY, Zheng X, Cui XX, Conney AH, Zhang K. Synthesis and evaluation of curcumin-related compounds for anticancer activity. Eur. J. Med. Chem., 53, 235-245 (2012).

28) Du ZY, Liu RR, Shao WY, Mao XP, Ma L, Gu LQ, Huang ZS, Chan AS. $\alpha$-Glucosidase inhibition of natural curcuminoids and curcumin analogs. Eur. J. Med. Chem., 41, 213-218 (2006). 